\title{
Trends in Municipal Finances in Uttar Pradesh
}

\section{Dr. A. K. Singh \\ Dr. M. P. Singh}

\section{Abstract}

Urban local governments are entrusted with a set of responsibilities of providing basic urban amenities and services to the people. They are dependent on states and centre for grant in aid and loans as the own resources of ULBs are grossly inadequate. There is mismatch between functions and municipal resources. The efforts for additional resource mobilization to fulfil the commitments by the ULBs are not adequate due to various factors. The ULBs are becoming dependent on transfers and fiscal devolution from central and state governments to meet out their financial requirements. Central Government has launched Missions and schemes for infrastructure development in selected cities and towns with massive financial investment. These schemes envisage strengthening of urban local bodies through introducing reforms and stepping up concrete efforts for additional resource mobilization. Thus, it is necessary to reduce dependence of local bodies on government support. They should effectively exploit the revenue potential through rationalization of assessment norms, simplification of procedures; rebate on timely payment, revision of old levies and taxes etc. Municipal governments may be allowed to enjoy fiscal autonomy with freedom of choice in regard to imposing new taxes and revising tax rates. It is argued that municipal bodies are not financially strong enough to tap capital market for undertaking infrastructure works which involve huge capital investment, long gestation period. But the provision of marketing borrowing will certainly motivate the municipal bodies to revamp their financial strength to mobilize resources from market. There is also need to encourage private sector involvement in the development, strengthening and creator of

\footnotetext{
* Assistant Director, RCUES, Lucknow University Campus, Lucknow ** Assistant Prof. Faculty of Management, Shri Ram Swaroop Group of Professional Colleges, Lucknow, Uttar Pradesh
} 
urban infrastructure. Against this backdrop, present paper purports to examine the emerging trends in municipal finances in Uttar Pradesh.

Keywords: Urban Local Government, Infrastructure Development, Private Sector, Municipal Income

\section{Introduction}

Cities are the engines of growth and leading edge of economic dynamism in a country. Cities are governed by urban local governments. As finance is the life blood of urban local governments, effective management of municipal financial resources is imperative besides concrete efforts for resource mobilization (Singh, 2011). The functional domain of ULBs in India considered of the provision of local public goods and services, including goods with merit characteristics. These comprised, in the main, public health including water supply, disposal of waste water, solid waste collection and disposal, city wide roads and streets, street lighting and other public amenities like parks and playgrounds. There has been mismatch between the existing municipal finances and functions delivered by the urban local governments. The efforts for augmenting the resources of municipal bodies in the country including essential reforms in the property tax system, collection and exploitation of user charges and fees for various services delivered by ULBs are not adequate( Rai and Singh,2010). The ULBs are depending on central and state transfers for meeting out their expenses. Government of India has launched JNNURM Mission to strengthen and improve efficiency of ULBs through introducing reforms and providing additional capital income to the selected ULBs for infrastructure development and improving the system of delivery of public services.

\section{Municipal Income in India}

Total revenues of ULBs in 2007-08 was Rs. 49,351 crore which increased to Rs.96,640 crore by 2012-13. Income from tax sources was Rs. 18,366 crore in 2007-08 constituting 37.2 percent of total revenues of ULBs in the country. But, its contribution declined to 32.0 percent by $2012-13$, though the actual tax income increased to 
Rs.30,912 crore. The share of non-tax revenues to total revenues more or less remained at the same level during the six year period at about 18.5 percent and 19.7 percent in 2007-08 and 2012-13 respectively, though the actual revenues more than doubled from Rs.9,134 crore to Rs. 19,002 crore during the period. The share of transfers from Government of India to total municipal revenues declined by 1.5 percent, though the actual income increased from Rs.3,515 crore to Rs.5,387 crore. The transfers from $12^{\text {th }}$ and $13^{\text {th }}$ Finance Commission grants increased by 1.9 percent to the total revenues and in actual terms they increased from Rs. 986 crore to Rs.3,760 crore during the period (Singh,2017)

The share of assignments and devolutions to total revenues remained at the same level with 19.0 percent, though in actual terms they doubled from Rs.9,342 crore to Rs. 18,537 crore between 2007-08 and 2012-13. State grants increased from 13.5 percent to 15.3 percent during the period and the income from other sources marginally increased by 1.7 percent. This indicates own sources of income are declining and income from external sources is increasing over a six year period. Own sources declined by 2.7percent in Municipal Corporations and Municipalities while it was recorded a decline of 2.0 percent in Nagar Panchayats. The analysis clearly brings out that there was a decline in the share of tax income and very marginal increase in the share of non-tax income, Finance Commission contributions and state grants-in - aid. The overall pattern is that the ULBs are not able to mobilize own sources and depend more on state and central transfers, devolutions, assignments and grants.

Own revenues of ULBs including taxes and non-taxes was Rs.27,501 crore constituting 55.7 percent of all ULB revenues but by 2012-13, they declined to 51.6 percent though in actual terms they rose to Rs.49,913 crore . Property tax is an important source of income to ULBs in all states across the country. Data on property tax is provided by only 19 states of the 28 states. The total property tax income of all three tiers during 2007-08 was Rs.8,159 crore which increased to Rs. 15,110 crore by $2012-13$ with a growth of 13.0 percent . By 2012-13, the Municipal Corporations more than doubled the 
property tax income withRs. 12,666 crore , municipalities marginally increased to Rs.2,201 crore and Nagar Panchayats rose by 50 percent to Rs. 243 crore The per capita property tax income of ULBs in 201213 was Rs.517 and those of Municipal Corporations Rs.813, municipalities Rs.206 and Nagar Panchayats a meagre Rs.70. The Municipal Corporations of Maharashtra have a per capita property tax income of Rs.1,787 followed by West Bengal with Rs.1,170 and the lowest was a mere Rs.45 in Rajasthan and Rs.68 in Uttarakhand. In municipalities, Gujarat is better with a per capita income of Rs.677 followed by Rs.617 in Kerala. The lowest is Rs.15 in Rajasthan and Madhya Pradesh. Among the Nagar Panchayats, Andhra Pradesh has a per capita income of Rs.471, which is higher than Rs.304 of municipalities. In Odisha, Assam and Tamil Nadu the per capita income of the third-tier is much higher than in several other states with Rs.269, Rs.199 and Rs.134 respectively. The lowest per capita of Nagar Panchayats was in Madhya Pradesh with only Rs.5 and Uttar Pradesh with Rs.11 and is marginally better in other states (Chari and Prasad, 2014).

Other taxes include advertisement tax, profession tax, vacant land tax, etc., which vary from state-to-state. Most states clubbed different non-property tax own sources 97 into 'others' and provided data. Other own tax revenues in 2007-08 was Rs.10,207 crore which increased to Rs.15,801 crore by 2012-13 with a CAGR of 9.1 percent. In case of Municipal Corporations the other own tax income was Rs.9,302 crore in 2007-08 and Rs.14,083 crore by 2012-13 with CAGR of 8.6 percent. Only19 States provided data on other taxes. In municipalities income from other tax sources was Rs.777 crore in 2007-08 and Rs.1,437 crore in 2012-13 with a CAGR of 13.1 percent. In Nagar Panchayats it was Rs. 129 crore in 2007-08 which more than doubled by 2012-13 to Rs.282 crore with a CAGR of about 17.0 percent (Table 4.2). The growth of non-property based other taxes is highest in Nagar Panchayats and lowest in Municipal Corporations. The per capita from other income of all three-tiers was Rs.578 with Municipal Corporations having Rs.952, municipalities Rs.145 and Nagar Panchayats with Rs.90. The per capita income of Municipal Corporations in 2012-13 was highest in Maharashtra with 
Rs.3,533 followed by Punjab which was almost half of Maharashtra with Rs.1,816 and in other states it varies very significantly. The lowest per capita income was Rs. 17 in Uttarakhand and Rs.23 in Andhra Pradesh. In municipalities more or less similar pattern emerges with Punjab having highest per capita of Rs.1,069 followed by Jammu \& Kashmir with Rs.547 and Kerala with Rs.491. The lowest was Rs.6.0 in Andhra Pradesh. In Nagar Panchayats the highest was in Punjab with Rs.1,110 followed by Tripura with Rs.690 and lowest being in Himachal Pradesh with Rs.3.0 .The ULBs mobilize revenues from different non-tax sources including water charges, fees and user charges, development charges, building permission fee, hiring charges, leasing amounts, etc. States provided data for all non-tax sources together than details of each non-tax source (Chari and Prasad, 20014).

The performance of a local body in the discharge of its various functions tends to be judged by the ways its revenues are spent, the tendencies of increase or decrease in expenditure. It is also to be noted that in the present time, rapid urbanization has resulted in more stress on municipal bodies in terms of meeting out the raising expectations of urban dwellers. The civic services are gradually declining in their quality. The process of urbanization and the problems arising out of it has awaken a national consensus and quite a number of civic problems are being now tackled at local level as well as they have become a national phenomenon. Housing, education, water supply, environmental pollution, employment opportunities, industrialization etc. can be effectively dealt with at national level. In respect of a number of services, therefore, the state is either taking upon itself the responsibility of implementing thee programmes by setting up its own statutory agencies or providing finances to local bodies for implementation by ways of loans and grants. This is another aspect, which has widened the scope of civic services and has considerably increased the expenditure of urban local bodies ( Singh et. al, 2014) . Moreover, after execution of the capital projects, the burden of maintenance and operational cost and debt services gradually falls on local bodies thereby increasing expenditure. The overall expenditure - both revenue and capital - was 
Rs. 44,554 crore in $2007-08$ which increased to Rs. 94,286 crore more than doubled in 2012-13. Revenue expenditure constituted 65.8 percent to total expenditure in 2007-08 which marginally declined to 63.7 percent by 2012-13 and the capital expenditure which was 34.2 percent, increased by 2.1 percent during the same period. In case of Municipal Corporations the ratio between revenue and capital expenditure remained the same during the period while in municipalities and Nagar Panchayats revenue expenditure declined by 7.9 percent and 5.7 percent respectively and consequently the capital expenditure increased accordingly which is a healthy sign (Singh,2017).

The revenue expenditure in ULBs of 24 states was Rs.29,302 Cr. in 2007-08 constituting 65.8 percent of the total expenditure which doubled to Rs.60,098 crore by 2012-13 which accounted for 63.7 percent . The per capita revenue expenditure was Rs.1,986 in 201213. It was almost one-and-a-half times more. The average was recorded Rs.2,869 in Municipal Corporations, Rs.962 municipalities and Rs.982 in Nagar Panchayats . The CAGR is 15.5 percent over a six-year period and 16.2 percent in Municipal Corporations and 13.1 percent and 13.2 percent in municipalities and Nagar Panchayats respectively. The capital expenditure in the ULBs was Rs.15,252 crore constituting 34.2 percent of the total expenditure in 2007-08, which more than doubled by 2012-13 to Rs.34,188 crore constituting 36.3 percent of the total expenditure - a CAGR of 17.5 percent . The per capita investment was Rs.1,491 in the Municipal Corporations while municipalities and NPs invested only Rs.790 and Rs.424 respectively. There are wide variations between states in capital expenditure. The revenue income - from taxes, non-taxes and assignments - has increased significantly over a six year period 2007-08 and 2012-13, from Rs. 30,702 crore to over Rs. 56,233 crore . But revenue expenditure increased from Rs.29,302 crore to Rs. 60,098 crore. Both income and expenditure was very high in Municipal Corporations as compared to municipalities and Nagar Panchayats. 
Municipal Finances in Uttar Pradesh:Municipal income in Uttar Pradesh is shown in Table 1. During 2016-17, out of total municipal income, government grant constituted 80.24 per cent while own revenue of ULBs accounted for 19.75 per cent. The proportion of own revenue against total municipal income was recorded high in Municipal Corporations (32.75 per cent). Again, tax revenue accounted for 12.6 per cent in ULBs while it was recorded 22.22 per cent in Municipal Corporations.

Table No 1: Municipal Income in Uttar Pradesh (2016-17)

(Rs. In Lakh)

\begin{tabular}{|l|c|c|c|c|}
\hline \multicolumn{1}{|c|}{ Type of ULBs } & Tax Revenue & $\begin{array}{c}\text { Non-Tax } \\
\text { Revenue }\end{array}$ & $\begin{array}{c}\text { Government } \\
\text { Grant }\end{array}$ & Total \\
\hline Nagar Nigam & 104779.03 & 49659.12 & 317046.14 & 471484.29 \\
& $(22.22)$ & $(10.53)$ & $(67.24)$ & $(100.0)$ \\
\hline Nagar Palika Parishad & 22721.84 & 18770.26 & 335492.93 & 376985.03 \\
& $(6.03)$ & $(4.98)$ & $(88.99)$ & $(100.0)$ \\
\hline Nagar Panchayat & 4798.54 & 6677.77 & 189898.02 & 201374.33 \\
& $(2.38)$ & $(3.46)$ & $(94.30)$ & $(100.0)$ \\
\hline Total & $\mathbf{1 3 2 2 9 9 . 4 1}$ & $\mathbf{7 5 1 0 7 . 1 5}$ & $\mathbf{8 4 2 4 3 7 . 0 9}$ & $\mathbf{1 0 4 9 8 4 3 . 6 5}$ \\
& $\mathbf{( 1 2 . 6 0 )}$ & $\mathbf{( 7 . 1 5 )}$ & $\mathbf{( 8 0 . 2 4 )}$ & $\mathbf{( 1 0 0 . 0 )}$ \\
\hline
\end{tabular}

Source: Department of Urban Development, Government of U.P., 2017-18

Chart No: 1

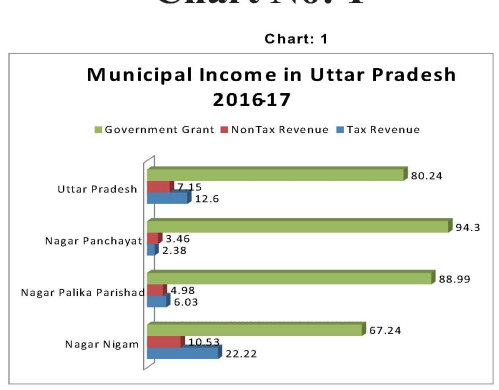

Proposed budget under AMRUT is shown in Table 2. Total budget under AMRUT was proposed in the tune of Rs. 11421.67 crores for 2015-16 to 2019-20. Out of total proposed budget, sewerage accounted for slightly less than half of the expenditure while less than half of the expenditure was reported under water supply. 
Table No 2 : Proposed Budget Under AMRUT in Uttar Pradesh

(Rs. In Crore)

\begin{tabular}{|l|c|c|c|}
\hline \multicolumn{1}{|c|}{ Head } & $\mathbf{2 0 1 5 - 1 6}$ & $\mathbf{2 0 1 6 - 1 7}$ & $\mathbf{2 0 1 7 - 2 0}$ \\
\hline Water Supply & 1519.19 & 2017.42 & 1996.02 \\
& $(46.21)$ & $(51.79)$ & $(47.08)$ \\
\hline Sewerage & 1697.62 & 1795.84 & 2149.46 \\
& $(51.64)$ & $(46.10)$ & $(47.08)$ \\
\hline Park & 70.45 & 81.90 & 93.76 \\
& $(2.14)$ & $(2.10)$ & $(2.211)$ \\
\hline Total & $\mathbf{3 2 8 7 . 2 7}$ & $\mathbf{3 8 9 5 . 1 6}$ & $\mathbf{4 2 3 9 . 2 4}$ \\
& $\mathbf{( 1 0 0 . 0 0 )}$ & $\mathbf{( 1 0 0 . 0 0 )}$ & $\mathbf{( 1 0 0 . 0 0 )}$ \\
\hline
\end{tabular}

Source: Department of Urban Development, Government of U.P., 2017-18

Chart No. 2 : Proposed Budget Under AMRUT in Uttar Pradesh

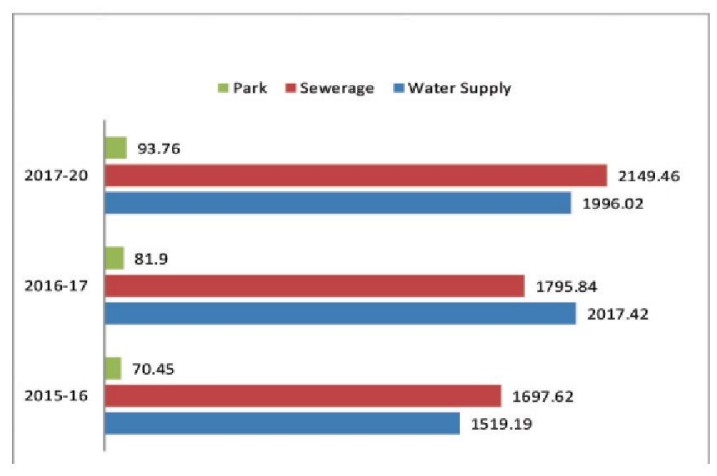

Income of ULBs in Uttar Pradesh for 2016-17 is shown in Table No. 3. Government grant constituted a large chunk of municipal revenue in all the selected cities however, it was recorded high in Bahraich as compared to other cities. Tax revenue constituted a larger share in Loni (9.48 per cent) as compared to other cities. Similarly, non-tax revenue constituted a larger share in Banda as compared to other cities. 


\section{Table No. 3 : Municipal Income in Selected Nagar Palika Parishads(2016-17)}

(Rs. In Lakh)

\begin{tabular}{|l|c|c|c|c|}
\hline \multicolumn{1}{|c|}{ Particulars } & Mirzapur & Loni & Banda & Bahraich \\
\hline Tax Revenue & 402.50 & 773.71 & 154.48 & 190.52 \\
& $(7.99)$ & $(9.48)$ & $(5.99)$ & $(5.96)$ \\
\hline \multirow{2}{*}{ Non-Tax Revenue } & 87.57 & 133.01 & 132.23 & 78.89 \\
& $(1.74)$ & $(1.63)$ & $(5.13)$ & $(2.47)$ \\
\hline \multirow{2}{*}{ Grant } & 4541.97 & 7257.74 & 2290.31 & 2919.40 \\
& $(90.26)$ & $(88.89)$ & $(88.87)$ & $(91.266)$ \\
\hline Total & 5031.98 & 8164.46 & 2577.02 & 3198.81 \\
& $(100.00)$ & $(100.00)$ & $(100.00)$ & $(100.00)$ \\
\hline
\end{tabular}

Source: Department of Urban Development, Government of U.P., 2017-18

\section{Chart No :3}

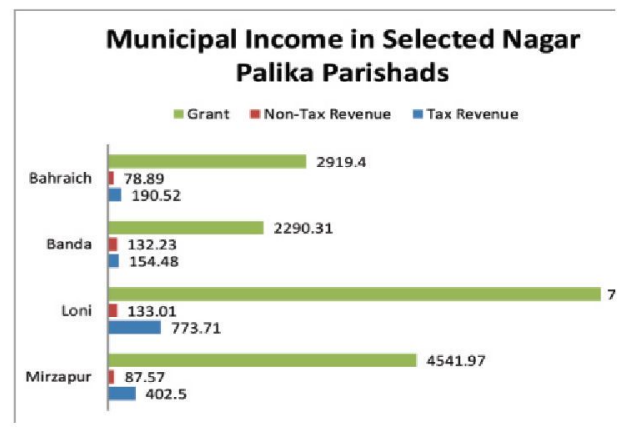

Present sanitation staff in ULBs in Uttar Pradesh is shown in Table No 4. Out of total sanitary staff in ULBs of Uttar Pradesh, slightly more than half of the staff was found on regular mode while more than $2 / 5^{\text {th }}$ staff was on contractual basis. The proportion of contractual staff was recorded high in Nagar Panchayats as compared to Municipal Corporations and Nagar Palika Parishads. 
Table No 4 : Present Sanitation Staff in ULBs in Uttar Pradesh

\begin{tabular}{|l|c|c|c|c|}
\hline \multicolumn{1}{|c|}{ ULB } & Regular & Daily Wages & Contractual & Total \\
\hline Nagar Nigam & $\begin{array}{c}16491 \\
(68.69)\end{array}$ & $\begin{array}{c}43 \\
(0.18)\end{array}$ & $\begin{array}{c}7473 \\
(31.13)\end{array}$ & $\begin{array}{c}24007 \\
(100.00)\end{array}$ \\
\hline Nagar Palika & 13333 & 173 & 12420 & 27903 \\
Parishad & $(47.78)$ & $(0.62)$ & $(44.51)$ & $(100.00)$ \\
\hline Nagar Panchayat & 3502 & 68 & 6584 & 10176 \\
& $(34.41)$ & $(0.67)$ & $(64.70)$ & $(100.00)$ \\
\hline \multicolumn{1}{|c|}{ Total } & $\mathbf{3 3 3 2 6}$ & $\mathbf{2 8 4}$ & $\mathbf{2 6 4 7 7}$ & $\mathbf{6 2 0 8 6}$ \\
& $\mathbf{( 5 3 . 6 8 )}$ & $\mathbf{( 0 . 4 5 )}$ & $\mathbf{( 4 2 . 6 5 )}$ & $\mathbf{( 1 0 0 . 0 0 )}$ \\
\hline
\end{tabular}

Source: Department of Urban Development, Government of U.P., 2017-18

Income and expenditure of ULBs is shown in Table No : 5. There has been an increasing trend in Municipal income and expenditure during the period 2014-15 to 2016-17. Significantly, there has been surplus of municipal income as expenditure was recorded low against municipal income in all the corresponding years.

Table No 5 : Income and Expenditure of ULBs

(Rs. In Crore)

\begin{tabular}{|l|c|c|c|}
\hline Income/Expenditure & $\mathbf{2 0 1 4 - 1 5}$ & $\mathbf{2 0 1 5 - 1 6}$ & $\mathbf{2 0 1 6 - 1 7}$ \\
\hline Income & & & \\
\hline Nagar Nigam & 4682.26 & 4251.82 & 4714.84 \\
\hline Nagar Palika Parishad & 3355.38 & 3523.98 & 3770.00 \\
\hline Nagar Panchayat & 2053.45 & 1992.60 & 2013.74 \\
\hline Total & $\mathbf{1 0 0 9 1 . 0 9}$ & $\mathbf{9 7 6 8 . 4 0}$ & $\mathbf{1 0 4 9 8 . 5 8}$ \\
\hline Expenditure & & & \\
\hline Nagar Nigam & 3205.52 & 3684.30 & 4115.92 \\
\hline Nagar Palika Parishad & 2884.11 & 3711.35 & 3615.03 \\
\hline Nagar Panchayat & 1770.07 & 2115.38 & 1862.35 \\
\hline \multicolumn{1}{|c|}{ Total } & $\mathbf{7 8 5 9 . 8 0}$ & $\mathbf{9 5 1 1 . 0 3}$ & $\mathbf{9 5 9 3 . 3 0}$ \\
\hline
\end{tabular}

Source: Department of Urban Development, Government of U.P., 2017-18 
Municipal expenditure in Uttar Pradesh during 2016-17 is shown in Table No 6. Out of total municipal expenditure, about $2 / 3^{\text {rd }}$ expenditure was reported on development and civic amenities while slightly more than $1 / 3^{\text {rd }}$ expenditure occurred on establishment. The proportion of expenditure on civic amenities and development was recorded high in Nagar Panchayats as compared to Municipal Corporations and Nagar Palika Parishads.

\section{Table No 6 : Municipal Expenditure in Uttar Pradesh} (2016-17)

\begin{tabular}{|l|c|c|c|}
\hline \multicolumn{1}{|c|}{ Type of ULBs } & $\begin{array}{c}\text { Civic Amenities and } \\
\text { Development }\end{array}$ & Establishment & Total \\
\hline Nagar Nigam & 249209.69 & 162382.36 & 411592.05 \\
& $(60.54)$ & $(39.45)$ & $(100.00)$ \\
\hline Nagar Palika & 231343.40 & 130160.23 & 361503.63 \\
Parishad & $(63.99)$ & $(36.01)$ & $(100.00)$ \\
\hline Nagar Panchayat & 144281.65 & 41954.07 & 186235.71 \\
& $(77.77)$ & $(22.53)$ & $(100.00)$ \\
\hline \multicolumn{1}{|c|}{ Total } & $\mathbf{6 2 4 8 3 4 . 7 4}$ & $\mathbf{3 3 4 4 9 6 . 6 6}$ & $\mathbf{9 5 9 3 3 1 . 3 9}$ \\
& $\mathbf{( 6 5 . 1 3 )}$ & $\mathbf{( 3 4 . 8 7 )}$ & $\mathbf{( 1 0 0 . 0 0 )}$ \\
\hline
\end{tabular}

Source: Department of Urban Development, Government of U.P., 2017-18

\section{Chart: 4}

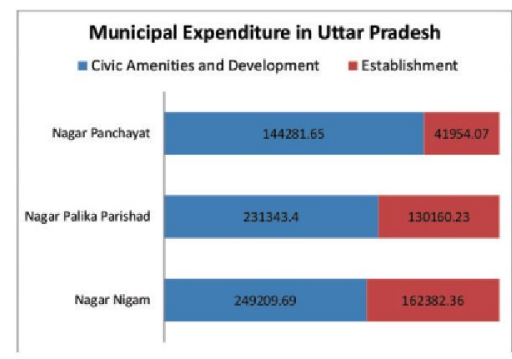


Expenditure on civic amenities in ULBs during 2016-17 is shown in Table No 7. Slightly less than $1 / 4^{\text {th }}$ expenditure was recorded on sanitary services during 2016-17. Expenditure on sanitation constituted higher share in Nagar Palika Parishads (25.78 per cent) followed by Nagar Panchayats (24.31 per cent) while it was recorded 20.55 per cent in Nagar Nigams.

Table No 7: Expenditure on Civic Amenities in ULBs (2016-17)

(Rs. In Crore)

\begin{tabular}{|l|c|c|c|c|}
\hline \multicolumn{1}{|c|}{ Head } & $\begin{array}{c}\text { Nagar } \\
\text { Nigam }\end{array}$ & $\begin{array}{c}\text { Nagar Palika } \\
\text { Parishad }\end{array}$ & $\begin{array}{c}\text { Nagar } \\
\text { Panchayat }\end{array}$ & Total \\
\hline Street Lighting & $\begin{array}{c}87.89 \\
(3.53)\end{array}$ & $\begin{array}{c}197.42 \\
(8.53)\end{array}$ & $\begin{array}{c}210.53 \\
(14.59)\end{array}$ & $\begin{array}{c}493.84 \\
(7.90)\end{array}$ \\
\hline Roads/Streets & 1019.90 & 1140.13 & 693.68 & 2853.71 \\
& $(40.92)$ & $(49.28)$ & $(48.08)$ & $(45.67)$ \\
\hline Building/Drains & 97.30 & 306.21 & 216.11 & 599.62 \\
& $(3.90)$ & $(13.24)$ & $(14.98)$ & $(9.59)$ \\
\hline Water Supply & 141.19 & 142.77 & 66.63 & 350.59 \\
& $(5.67)$ & $(6.17)$ & $(4.62)$ & $(5.61)$ \\
\hline Sanitation & 240.40 & 138.78 & 67.96 & 447.14 \\
Equipments/Sanitation & $\mathbf{( 9 . 6 4 )}$ & $(5.99)$ & $(4.71)$ & $(7.16)$ \\
Services & & & & \\
\hline Sewerage & 33.39 & 8.81 & 0.11 & 42.31 \\
& $(1.34)$ & $(0.38)$ & $(0.00)$ & $(0.68)$ \\
\hline Advertisement & 6.54 & 16.70 & 17.60 & 40.84 \\
& $(0.26)$ & $(0.72)$ & $(1.22)$ & $(0.65)$ \\
\hline Others & 865.48 & 364.61 & 190.20 & 142.29 \\
& $(34.73)$ & $(15.76)$ & $(13.18)$ & $(2.28)$ \\
\hline Total & $\mathbf{2 4 9 2 . 0 9}$ & $\mathbf{2 3 1 3 . 4 3}$ & $\mathbf{1 4 4 2 . 8 2}$ & $\mathbf{6 2 4 8 . 3 4}$ \\
& $\mathbf{( 1 0 0 . 0 0 )}$ & $\mathbf{( 1 0 0 . 0 0 )}$ & $\mathbf{( 1 0 0 . 0 0 )}$ & $\mathbf{( 1 0 0 . 0 0 )}$ \\
\hline
\end{tabular}

Source: Department of Urban Development, Government of U.P., 2017-18 


\section{Chart : 5}

Expenditure on Civic Amenities in ULBs

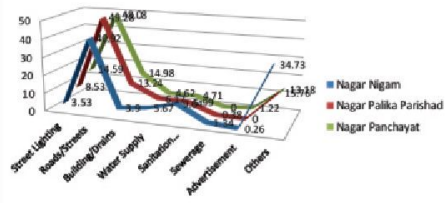

Municipal expenditure in selected ULBs during 2016-17 is shown in Table No 8. The proportion of expenditure on sanitation services against total municipal expenditure was recorded high in Banda (11.69 per cent) followed by Mirzapur (9.3 per cent), Bahraich (6.07 per cent) and lowest in Loni (3.91 per cent).

Table No 8 : Municipal Expenditure in Selected Nagar Palika Parishads (2016-17)

(Rs. in Lakh)

\begin{tabular}{|c|c|c|c|c|}
\hline Particulars & Mirzapur & Loni & Banda & Bahraich \\
\hline Street Lighting & $\begin{array}{l}122.18 \\
(3.68)\end{array}$ & $\begin{array}{r}138.70 \\
(1.60)\end{array}$ & $\begin{array}{l}114.17 \\
(5.17)\end{array}$ & $\begin{array}{l}74.06 \\
(2.36)\end{array}$ \\
\hline $\begin{array}{l}\text { Road Construction } \\
\text { / Repair }\end{array}$ & $\begin{array}{l}152.33 \\
(4.59)\end{array}$ & $\begin{array}{l}736.76 \\
(8.50)\end{array}$ & $\begin{array}{c}556.70 \\
(25.22)\end{array}$ & $\begin{array}{l}1078.21 \\
(34.40)\end{array}$ \\
\hline Building / Drains & $\begin{array}{l}92.97 \\
(2.80)\end{array}$ & $\begin{array}{l}20.29 \\
(0.23)\end{array}$ & $\begin{array}{c}79.41 \\
(3.60)\end{array}$ & $\begin{array}{l}37.90 \\
(1.21)\end{array}$ \\
\hline $\begin{array}{l}\text { Sanitation } \\
\text { Equipments / } \\
\text { Sanitation }\end{array}$ & $\begin{array}{l}63.99 \\
(1.93)\end{array}$ & $\begin{array}{c}72.33 \\
((0.83)\end{array}$ & $\begin{array}{l}187.71 \\
(8.09)\end{array}$ & $\begin{array}{l}123.05 \\
(3.93)\end{array}$ \\
\hline Water Supply & $\begin{array}{l}158.37 \\
(4.77)\end{array}$ & $\begin{array}{c}246.75 \\
(2.85)\end{array}$ & - & $\begin{array}{l}29.22 \\
(0.93)\end{array}$ \\
\hline Sewerage & - & - & - & - \\
\hline Advertisement & $\begin{array}{l}0.11 \\
(0.00)\end{array}$ & $\begin{array}{l}25.60 \\
(0.29)\end{array}$ & $\begin{array}{l}12.43 \\
(0.56)\end{array}$ & $\begin{array}{l}16.06 \\
(0.51)\end{array}$ \\
\hline Other & $\begin{array}{l}722.80 \\
(21.79)\end{array}$ & $\begin{array}{r}175.60 \\
(2.03)\end{array}$ & $\begin{array}{l}55.55 \\
(2.52)\end{array}$ & $\begin{array}{l}87.42 \\
(2.79)\end{array}$ \\
\hline
\end{tabular}




\begin{tabular}{|l|c|c|c|c|}
\hline Total (Civic Services) & $\begin{array}{c}1312.75 \\
(39.58)\end{array}$ & $\begin{array}{c}7415.53 \\
(85.58)\end{array}$ & $\begin{array}{c}1001.07 \\
(45.34)\end{array}$ & $\begin{array}{c}1446.02 \\
(46.14)\end{array}$ \\
\hline Establishment & 2004.29 & 1249.84 & 1206.64 & $\begin{array}{c}1587.95 \\
(60.42)\end{array}$ \\
& $(14.42)$ & $(54.66)$ & $(50.66)$ \\
\hline Grand Total & 3317.04 & 8665.37 & 2207.71 & 3133.97 \\
& $(100.00)$ & $(100.00)$ & $(100.00)$ & $(100.00)$ \\
\hline
\end{tabular}

Source: Department of Urban Development, Government of U.P., 2017-18

\section{Chart No: 6}

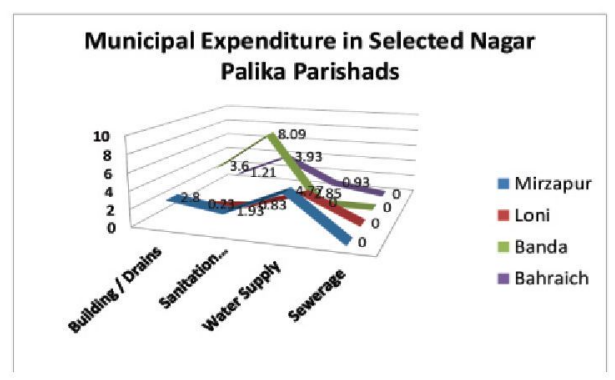

Table No 9 : Per Capita Expenditure on Development /Civic Services in Uttar Pradesh

\begin{tabular}{|l|c|c|c|c|c|c|}
\hline \multirow{2}{*}{ ULBs } & \multicolumn{2}{|c|}{$\begin{array}{l}\text { Development } \\
\text { Civic Services }\end{array}$} & \multicolumn{2}{c|}{ Establishment } & \multicolumn{2}{c|}{ Total } \\
\cline { 2 - 7 } & $\mathbf{2 0 1 5 - 1 6}$ & $\mathbf{2 0 1 6 - 1 7}$ & $\mathbf{2 0 1 5 - 1 6}$ & $\mathbf{2 0 1 6 - 1 7}$ & $\mathbf{2 0 1 5 - 1 6}$ & $\mathbf{2 0 1 6 - 1 7}$ \\
\hline $\begin{array}{l}\text { Nagar } \\
\text { Nigam }\end{array}$ & 1245.75 & $\mathbf{1 4 1 3 . 0}$ & 838.58 & 920.85 & 2084.33 & 2334 \\
\hline $\begin{array}{l}\text { Nagar } \\
\text { Palika } \\
\text { Parishad }\end{array}$ & 1637.79 & 1455.0 & 795.43 & 818.67 & 2433.22 & 2273.75 \\
\hline $\begin{array}{l}\text { Nagar } \\
\text { Panchayat }\end{array}$ & 2417.95 & 198.10 & 567.90 & 576.05 & 2935.85 & 2350.32 \\
\hline \multicolumn{1}{|c|}{ Total } & $\mathbf{1 7 6 7 . 1 6}$ & $\mathbf{4 0 8 . 1 7}$ & $\mathbf{7 1 7 . 3}$ & $\mathbf{8 1 9 . 5 0}$ & $\mathbf{2 4 8 4 . 4 7}$ & $\mathbf{2 5 5 7 . 1 2}$ \\
\hline
\end{tabular}

Source: Department of Urban Development, Government of U.P., 2017-18 
Per capita expenditure on development /civic services in Uttar Pradesh is shown in Table No 9. Per capita expenditure on development and civic services has declined however; per capita expenditure on establishment has increased significantly over the period of 2015-16 to 2016-17. Per capita expenditure was recorded high in Nagar Panchayats as compared to Nagar Palika Parishads and Nagar Nigams.

\section{Chart 7}

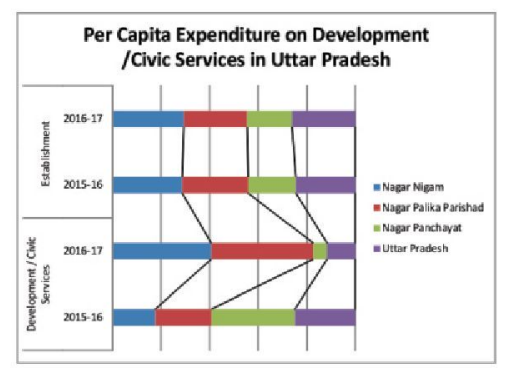

\section{Conclusion}

It is clear from the above analysis that the present institutional arrangements for the provision of urban services is unlikely to sustain in the face of mounting fiscal pressures on municipal bodies and the rapid demand for urban services. The new economic policies, oriented towards market based economy led growth objectives, would also entail a significant contribution of the urban sector and efforts would be needed to reduce infrastructure bottlenecks and increase urban productivity and employment. The growing fiscal stress on municipal bodies will require fiscal corrections, effective fiscal management, and resources mobilization through initiating financing reforms. Moreover, legislative exercises to precisely define the functions and finances of municipal bodies especially after functional devolution as per $74^{\text {th }}$ Amendment Act are needed. Again, there should be re-assessments of finances of municipal bodies after complete functional devolution. Introduction of administrative reforms to develop an accountable municipal bureaucracy with suitably design policies regarding staff recruitment, incentives and penalties to ensure results, results, performance contracting etc. is 
also called for. Training of newly elected municipal representatives and municipal officials regarding the Constitutional mandates and especially effective fiscal management/ administration is also needed. As per fiscal needs of municipal bodies, State Governments should make serious efforts for resource mobilization through enlarging fiscal domain of local bodies and its resource base. It is necessary to reduce dependence of local bodies on government budgetary support. They should effectively exploit the revenue potential through rationalization of assessment norms, simplification of procedures; rebate on timely payment, revision of old levies and taxes. Municipal governments may be allowed to enjoy fiscal autonomy with freedom of choice in regard to imposing new taxes and revising tax rates. It is argued that municipal bodies are not financially strong enough to tap capital market for undertaking infrastructure works which involve huge capital investment, long gestation period. But the provision of marketing borrowing will certainly motivate the municipal bodies to revamp their financial strength to mobilize resources from market.

\section{References}

Chary, V. Srinivas and D. Ravindra Prasad (2014) Municipal Finances and Service Delivery in India, ASCI, Hyderabad

Rai, N. and Singh, A.K. (2010), New Dimensions in Urban Management, Serials Publications, New Delhi

Singh, A. K. (2017) Municipal Finances in India: A Study of Ranchi Municipal Corporation in Jharkhand, RCUES, Lucknow

Singh, A.K. (2011), Inclusive Urban Development in India, Training Module, RCUES, Lucknow

Singh, U.B. et.al. (2014), Challenges of Urban Governance in India in New Millennium, Global Research Publications, New Delhi. 